American Journal of Biochemistry and Biotechnology 6 (2): 89-102, 2010

ISSN 1553-3468

(C) 2010 Science Publications

\title{
A Proteomics Analysis of Drought Stress-Responsive Proteins as Biomarker for Drought-Tolerant Sugarcane Cultivars
}

\author{
${ }^{1}$ Nisachon Jangpromma, ${ }^{1}$ Supansa Kitthaisong, ${ }^{1}$ Khomsorn Lomthaisong, \\ ${ }^{1}$ Sakda Daduang, ${ }^{2}$ Prasit Jaisil and ${ }^{1}$ Sompong Thammasirirak \\ ${ }^{1}$ Protein and Proteomics Research Group, Department of Biochemistry, Faculty of Science, \\ ${ }^{2}$ Department of Plant Science and Agricultural Resources, Faculty of Agriculture, \\ Khon Kaen University, Khon Kaen, 40002, Thailand
}

\begin{abstract}
Problem statement: The prime objective in breeding selection process of drought-tolerant sugarcane is to identify the correlating marker, which could lead to rapid screening for drought-tolerant cultivars. In this study, we have reported an unknown 18-kDa protein (p18) along with other stress-inducible proteins to be highly expressed in sugarcane leaves under drought stress condition. Approach: The 2DPAGE patterns of proteins were compared between those expressed in drought-tolerance K86-161 and drought-susceptible Khon Kaen 1 cultivars. The interested proteins were identified by mass spectrometry. The correlation between p18 expression and drought tolerance was verified in additional 4 sugarcane cultivars using ELISA and western blotting. Two physiological indexes, Chlorophyll content and SOD activity were also evaluated. Results: Mass spectrometry and comparison with known sequences in the database reveal that the proteins expressed only in stressed K86-161 are serine protease inhibitor and the one similar to replication protein A1. A group of proteins up-regulated in K86-161 are SAdenosylmethionine decarboxylase proenzyme (SAM), ubiquitin and p18. From ELISA and western blotting analysis, we found that p18 expressed in drought-tolerant sugarcane cultivars had higher binding specificity to antibody than that in drought-susceptible sugarcane cultivars. Two physiological indexes showed higher levels in drought-tolerant than those in drought susceptible sugarcanes. Conclusion: These high levels of chlorophyll and SOD are in agreement with a high level of p18 expression in droughttolerant sugarcanes. It is likely that an accumulation of p18 is a response to water deficit. In conclusion, p18 might be a good candidate for development as a marker in drought-tolerant plants.
\end{abstract}

Key words: Drought tolerance, protein biomarker, Saccharum officinarum L., two-dimensional polyacrylamide gel electrophoresis

\section{INTRODUCTION}

Sugarcane (Saccharum officinarum L.) is the main source for sugar production and plays a vital economic role in many tropical countries. It is also a prime fuel crop candidate due to efficient biomass production (Zhang et al., 2006). In Thailand, sugarcane is one of the major industrial crops. The total production of sugarcane in Thailand is the 9th largest in the world. However, the export of Thailand's sugar production is the 3rd highest percentage in the world, following Australia (76\%) and Brazil (59\%) (Workman, 2007). The main growing area in Thailand is in the Northeastern part of the country. Although a large area is available, the areas geographically suitable for sugarcane growing are usually very drought-prone.
Having low capacity of water retention in such areas generally results in low yields of sugarcane.

Drought is one of the most severe limitations on the yield of sugarcane. This stress induces various biochemical and physiological responses in plants as a survival mechanism (Seki et al., 2003). Various strategies are developed in plants under water-deficit conditions. In terms of biochemical responses, water stress induces accumulation of functioning solutes, such as proline, sugar, sugar alcohol and betaine in plants (Ingram and Bartels, 1996; Rhodes and Hanson, 1993). These compounds facilitate adaptation of plants under severe circumstances. Regarding the genetic responses, a variety of genes has been reported to be induced by water deficit in various plant species. The function of the expressed proteins has been predicted to play a vital

Corresponding Author: Sompong Thammasirirak, Protein and Proteomics Research Group, Department of Biochemistry, Faculty of Science, Khon Kaen University, Khon Kaen, 40002, Thailand Tel: +66-43-342-911 Fax: +66-43-342-911 
role in the adaptive response to stress (Ingram and Bartels, 1996; Bray, 1997; Seki et al., 2001). The products of these stress-inducible genes have been classified into two groups: Proteins directly protecting against drought stress and proteins involved in regulation of gene expression and signal transduction. The first group includes proteins that probably function by protecting cells from dehydration, such as the enzymes required for the biosynthesis of various osmoprotectants, late embryogenesis abundant proteins and detoxification enzymes. The second group includes regulatory proteins such as transcription factors and protein kinases (Seki et al., 2003; Shinozaki and Yamaguchi-Shinozaki, 2000). Identification of such biochemical markers is of great importance in plant breeding strategy since this could help to improve field performance under drought conditions.

Attempts to identify markers to determine droughttolerant characteristics in sugarcane cultivars have been pursued for many decades. The supporting evidence suggests that markers could be divided into three broad categories: Morphological, cytogenetic and biochemical markers. The first group is the morphological markers. These markers are first to be utilized. They are based on the traditional botanical descriptions of visible characters. These characters have limitation if used as markers in sugarcane because they are not inherited in a simple Mendelian manner (Hogarth, 1987). The second group is the cytogenetic markers. They are based on the observation in mitotic and meiotic chromosomes that can provide additional information apart from morphological markers. However, the small and variable size of sugarcane chromosomes and their abnormal pairing behavior make cytogenetic observation difficult (Sreenivasan et al., 1987). The third group that has becomes a popular tool in plant genetics is the biochemical markers. These markers are based on the expression of proteins and secondary metabolites. Studies utilizing these markers have also initiated in sugarcane (Ramagopal, 1990). Proteins and secondary metabolites in leaves have been examined to be promising as markers. For instance, a sample are dehydrin (Jiang and Huang, 2002; Lopez et al., 2001; 2003), superoxide dismutase (Zang and Komatsu, 2007), ASR (ABA-water stress-ripening-induced) protein (Riccardi et al., 1998) and actin depolymerizing factor (Salekdeh et al., 2002).

Proteomics is a powerful technique for separating complex protein mixtures. Changes in protein profiles in response to environmental effects can be determined with this method. In this study we used this technique to analyze the physiological function of sugarcane-leaf proteins involved in drought stress. Accumulation of p18 was identified by ELISA and western blotting technique using polyclonal antibody against droughttolerant sugarcane protein produced in mice. Further, we found that the p18 showed higher intensity in drought-tolerant sugarcane cultivars than that of drought-susceptible cultivars. This induction was correlated with two physical indicators (chlorophyll content and superoxide dismutase) that had highest concentration in drought-tolerant cultivars. The primary structure of this protein might be in the group of Late Embryogenesis Abundant (LEA) protein. We propose that $\mathrm{p} 18$ is functional under drought by preventing water loss from sugarcane leaves.

\section{MATERIALS AND METHODS}

Plant culture and stress treatment: Changes in protein expression patterns in response to drought stress were studied, comparing between two different cultivars of sugarcane plants: K86-161 (droughttolerant) and Khon Kaen 1 (drought-susceptible). They were grown in greenhouse for later examination on drought tolerance that has been described previously (Jangpromma et al., 2007). The K86-161 cultivar was selected as the drought-tolerant strain, using the criteria gives by the Office of the Cane and Sugar Board, The Cane and Sugar Promotion Center, Region 1 Kanchanaburi, Thailand, by open-pollination of ROC 1. K86-161 is a high-yielded cultivar and resistant to major diseases. It shows high tolerance to drought conditions and can grow in every type of soil. The representative drought-susceptible cultivar is Khon Kaen 1, a cross breeding between Uthong 1 and ROC 1 at Khon Kaen Field Crop Research Center, Department of Agriculture, Khon Kaen (90-2-029). This cultivar gives high sugar yield, high Commercial Cane Sugar (CCS) and resistance to red rot wilt disease. However, it is very sensitive to drought conditions in Khon Kaen soils. The two representative cultivars were obtained from Khon Kaen Field Crop Research Center in Khon Kaen Province; the Northeast of Thailand. In the greenhouse, propagative organs of K86-161 and Khon Kaen 1 were grown in pots $(50 \mathrm{~cm}$ in diameter and $30 \mathrm{~cm}$ deep) containing topsoil at natural light condition. Soil had $\mathrm{pH}$ at 4.75, total nitrogen concentration at $0.0255 \%$, Field Capacity (FC) at $12.26 \%$ and Permanent Wilting Point (PWP) at 3.36\%. After 3 months growth, K86-161 and Khon Kaen 1 sugarcane plants were stopped from being watered for 3 weeks. Leaf samples were harvested from stressed and control (well-watered conditions) plants after drought treatment. Samples were stored at $-70^{\circ} \mathrm{C}$. For other measurement, each sugarcane plant was propagated and grown in the field under natural conditions. 
Measurements of physiological parameters: The excised leaves of sugarcane plants grown under drought or control condition were subject to measurement for leaf Relative Water Content (RWC), chlorophyll a and b contents and Superoxide Dismutase (SOD) activity.

RWC was determined according to the method of Barrs and Weatherley (1962) based on the following calculation:

$$
\mathrm{RWC}=[(\mathrm{FW}-\mathrm{DW}) /(\mathrm{SW}-\mathrm{DW})] \times 100
$$

Where:

$\mathrm{FW}=$ Fresh weight of leaves

DW $=$ Dry weight of leaves after drying at $80^{\circ} \mathrm{C}$

$\mathrm{SW}=$ The saturated or turgid weight of leaves after soaking in water for $8 \mathrm{~h}$ at room temperature

The chlorophyll content in leaves was measured by the method described by Moran (1982). In brief, leaf tissue from each cultivar was cut into a circular shape $\left(0.5 \mathrm{~cm}^{2}\right)$. The piece of leaf was placed in a vial containing $2.5 \mathrm{~mL}$ DMF (N, N-dimethylformamide) and left for $24 \mathrm{~h}$ in the dark. The experiment was done triplicate. The total chlorophyll extract was spectrophotometrically measured at 647 and $664 \mathrm{~nm}$, respectively. The equations to calculate for total chlorophyll (Chl t), chlorophyll a $(\mathrm{Chl}$ a) and chlorophyll $\mathrm{b}(\mathrm{Chl} \mathrm{b})$ were based on the following:

$$
\begin{aligned}
& \text { Chl a }\left(\mu \mathrm{g} \mathrm{mL}^{-1}\right)=12.64 \mathrm{~A}_{664}-2.99 \mathrm{~A}_{647} \\
& \text { Chl b }\left(\mu \mathrm{g} \mathrm{mL}^{-1}\right)=-5.6 \mathrm{~A}_{664}+23.24 \mathrm{~A}_{647} \\
& \text { Chl t }\left(\mu \mathrm{g} \mathrm{mL}^{-1}\right)=7.04 \mathrm{~A}_{664}+20.27 \mathrm{~A}_{647}
\end{aligned}
$$

SOD activity in extract of sugarcane leaves was performed by indirect spectrophotometric method according to Spychalla and Desborough (1990) with minor modification. In brief, sugarcane leaves $(1 \mathrm{~g})$ were ground to fine powder using liquid nitrogen and suspended in extraction buffer $\left(50 \mathrm{mM} \mathrm{K} \mathrm{HPO}_{4} / \mathrm{KH}_{2} \mathrm{PO}_{4}\right.$ buffer (pH 7.8), $1 \mathrm{mM}$ EDTA). The homogenate was centrifuged at $8000 \mathrm{xg}, 4^{\circ} \mathrm{C}$, for $15 \mathrm{~min}$. The supernatant was kept for enzyme assay. The assay, having the reaction mixture of $50 \mathrm{mM} \mathrm{K} \mathrm{HPO}_{4} / \mathrm{KH}_{2} \mathrm{PO}_{4}(\mathrm{pH} 7.8)$, $0.1 \mathrm{mM}$ EDTA, $0.8 \mathrm{mM}$ cytochrome c and $4.0 \mathrm{mM}$ xanthine, was performed in a $1 \mathrm{~mL}$ cuvette at $25^{\circ} \mathrm{C}$ with a recording spectrophotometer. The assay was initiated by the addition of sufficient xanthine oxidase to produce a basal rate of cytochrome $\mathrm{c}$ reduction corresponding to an increase in $\mathrm{A}_{550}$ for 0.035 units $\min ^{-1}\left(\mathrm{~V}_{1}\right)$. After verification of $\mathrm{V}_{1}$, sugarcane leaf extract was added and the resulting reaction Velocity $\left(\mathrm{V}_{2}\right)$ was calculated. One unit of SOD was defined as the amount of enzyme that inhibited the rate of cytochrome c reduction by $50 \%\left(\mathrm{~V}_{1} / \mathrm{V}_{2}=2\right)$ in a $1 \mathrm{~mL}$ assay.

Protein extraction for electrophoresis: Extraction of protein from sugarcane leaves was performed as previously described by Jangpromma et al. (2007). Briefly, $0.5 \mathrm{~g}$ of sugarcane leaves were ground to fine powder using liquid nitrogen and suspended in $2 \mathrm{~mL}$ lysis buffer (7 M urea, $2 \mathrm{M}$ thiourea, $4 \%$ (w/v) CHAPS, $2 \%(\mathrm{w} / \mathrm{v})$ DTT, $0.8 \%$ (w/v) IPG buffer). The homogenate was centrifuged at $10000 \times \mathrm{g}, 4^{\circ} \mathrm{C}$, for $30 \mathrm{~min}$. The supernatant was transferred to a new $1.5 \mathrm{~mL}$ tube. Contaminants were removed by 2D-Clean up kit (Amersham Bioscience, Sweden). Pellets were resuspended in rehydration buffer containing $7 \mathrm{M}$ urea, $2 \mathrm{M}$ thiourea, 2\% (w/v) CHAPS, $2 \mathrm{mM}$ DTT, 0.8\% (w/v) IPG buffer and $0.2 \%$ bromophenol blue. Protein concentration was determined by Bradford (1976) assay using BSA as the standard.

Protein analysis by gel electrophoresis: The 1Dimensional (1-D) and 2-Dimensional (2-D) electrophoresis were performed as previously described by Jangpromma et al. (2007). Briefly, One-dimensional Polyacrylamide Gel Electrophoresis (SDS-PAGE) was using $15 \%$ separating gel and $4 \%$ stacking gel. The following molecular mass standards (Amersham Bioscience, USA) were run alongside the extracted proteins: Phosphorylase b, $97 \mathrm{kDa}$; albumin, $66 \mathrm{kDa}$; ovalbumin, $45 \mathrm{kDa}$; carbonic anhydrase, $30 \mathrm{kDa}$; trypsin inhibitor, $20.1 \mathrm{kDa}$ and $\alpha$ lactalbumin, $14.4 \mathrm{kDa}$. Proteins were stained with Coomassie brilliant blue R250.

Two-Dimensional (2-D) electrophoresis was performed according to a modified method of O'Farrell (1975). In the first dimensional isoelectric focusing gel, proteins were resuspended in the rehydration buffer $(7 \mathrm{M}$ urea, $2 \mathrm{M}$ thiourea, 2\% (w/v) CHAPS, $2 \mathrm{mM}$ DTT, $0.8 \%(\mathrm{w} / \mathrm{v})$ IPG buffer and $0.2 \%$ bromophenol blue). IEF was performed on $7 \mathrm{~cm}$ or $13 \mathrm{~cm}$ immobilized $\mathrm{pH}$ gradient gels (Amersham Bioscience, Sweden). An adequate amount of protein was loaded onto the strip holder $(100 \mu \mathrm{g}$ for IPG strip $7 \mathrm{~cm}$ and $250 \mu \mathrm{g}$ for IPG strip $13 \mathrm{~cm}, \mathrm{pH} 4-7)$. The second dimension SDS gel used $15 \%$ acrylamide. The molecular mass standards were the same as in 1D PAGE. Following electrophoresis of the second dimension, proteins were stained with silver nitrate (Amersham Bioscience, USA).

Mass spectrometry: For mass spectrometry analysis and protein identification, the silver-stained protein spots were excised from preparative polyacrylamide 
gels. The gel pieces were prepared for trypsin digestion using an 5 Ettan Spot Handling Workstation (Amersham Bioscience) according to the manufacturer's specifications using sequencing grade modified trypsin (Promega). Following digestion and extraction, the peptides were spotted onto MALDI targets. The mass spectra were recorded on a reflector Bruker reflex V delayed extraction MALDI-TOF mass spectrometer equipped with a $2 \mathrm{GHz}$ LeCroy digitizer and $337 \mathrm{~nm}$ N2laser. Instrumental parameters were: positive polarity, acceleration voltage $20 \mathrm{kV}$; IS/2 $17 \mathrm{kV}$; focusing lens voltage $8.90 \mathrm{kV}$; extraction delay 400 ns. The detector was gated. Typically 100 shots were accumulated from three to five different positions within a sample spot. Protein identifications were obtained using MASCOT (http://www.matrixscience.com) and by searching for matching peptide mass fingerprints in a protein database.

Production of polyclonal antibody: The protocol was the same as described in previous study (Jangpromma et al., 2007). Total proteins $(500 \mu \mathrm{g})$ were separated by SDSPAGE and the bands of proteins correlating to drought stress were excised from the gels. After lyophilization, the dry gel was ground to a fine powder and resuspended in $1-2 \mathrm{~mL}$ of PBS buffer $(135 \mathrm{mM} \mathrm{NaCl}, 1.5 \mathrm{mM}$ $\mathrm{KH}_{2} \mathrm{PO}_{4}, 2.5 \mathrm{mM} \mathrm{KCl}, 8 \mathrm{mM} \mathrm{Na} \mathrm{HPO}_{4}$ ). Protein suspension was emulsified with Freund's complete adjuvant (Sigma, USA). About $100 \mu \mathrm{L}$ of the emulsion was subcutaneously injected into the mouse. Two weeks following the second boost, the same emulsion but containing Freund's incomplete adjuvant (Sigma, USA) was subcutaneously injected into the mouse at intervals over 8 weeks. Blood was drawn 2 weeks after the last injection and allowed to clot overnight at $4{ }^{\circ} \mathrm{C}$. The serum was collected by centrifugation at $8000 \times \mathrm{g}$ for $10 \mathrm{~min}$ and then the supernatant containing antiserum was pooled and used for Western blotting and Enzyme linked immunosorbent assay.

Enzyme linked immunosorbent assay: Sugarcane leaves $(1 \mathrm{~g})$ were ground to fine powder using liquid nitrogen and suspended in extraction buffer (PBS buffer $\mathrm{pH} 7.4$ containing $1 \mathrm{mM}$ PMSF, $1 \mathrm{mM}$ ABZM and $100 \mathrm{mg}$ PVP per $\mathrm{g}$ of sample) and filtered through layers of gauze to remove big particles. The crude lysate was determined for protein concentration by Bradford (1976) assay. The ELISA assay was carried out on a 96-well microtiter-plate (Nalge Nunc International, Denmark). Each well of the polystyrene microtiter- plate was coated with $50 \mu \mathrm{L}$ of $0.02 \mu \mathrm{g} \mu \mathrm{L}-$ 1 sample lysate (as antigen) and incubated overnight at $4^{\circ} \mathrm{C}$. The weakly bound antigen was washed with TBST (TBS: $10 \mathrm{mM}$ Tris-HCl, $\mathrm{pH} 8.0$ and $150 \mathrm{mM} \mathrm{NaCl}$ containing $0.05 \%(\mathrm{v} / \mathrm{v})$ Tween-20) and the wells were blocked with $100 \mu \mathrm{L}$ of blocking solution $(5 \%(\mathrm{w} / \mathrm{v})$ skimmed milk in TBST) for $1 \mathrm{~h}$ at $37^{\circ} \mathrm{C}$. After three rinses with TBST, $50 \mu \mathrm{L}$ of suitably diluted antiserum in blocking solution $(1: 100, \mathrm{v} / \mathrm{v})$ was incubated in each well for $1 \mathrm{~h}$ at $37^{\circ} \mathrm{C}$. The wells were washed again with TBST and incubated with secondary antibody coupled with alkaline phosphatase diluted in TBST. Following incubation at $37^{\circ} \mathrm{C}$ for $1 \mathrm{~h}$, the wells were washed three times with TBST, followed by TBS. Bound antiserum was detected using freshly prepared chromogenic substrate $\left(1 \mathrm{mg} \mathrm{mL}^{-1}\right.$ of $\rho$ nitrophenyl phosphate, $100 \mathrm{mM}$ Tris- $\mathrm{HCl}, \mathrm{pH}$ 9.5, $100 \mathrm{mM} \mathrm{NaCl}$ and $50 \mathrm{mM} \mathrm{MgCl}_{2}$ ). Absorbance was measured at $405 \mathrm{~nm}\left(\mathrm{~A}_{405}\right)$ by ELISA plate reader.

Western blotting analysis: Western blotting analysis was performed as previously described by Jangpromma et al. (2007).

\section{RESULTS}

Study of drought-tolerant sugarcane cultivar by stress conditions: Changes of protein expression patterns and development in leaves were compared between two plant models: Drought-tolerant K86-161 and drought-susceptible Khon Kaen 1 cultivars. As described previously (Jangpromma et al., 2007) after water-deficit treatment, the leaves of Khon Kaen 1 cultivar became wilted and yellow. In contrast, K86161 leaves were in normal green color and could grow throughout the experiment. The leaves Relative Water Content (RWC) of Khon Kaen 1 decreased to about $60 \%$, but RWC of K86-161 remained stable at $86 \%$. These results demonstrate that K86-161 has better tolerance to drought than Khon Kaen 1 sugarcane cultivar. They were therefore selected as the droughttolerant and drought-susceptible model plants for selection of protein biomarker.

Comparison of protein expression patterns in K86161 and Khon Kaen 1 under drought conditions: In this study, protein expression patterns were compared between drought-tolerant (K86-161) and droughtsusceptible (Khon Kaen 1) cultivars. Total proteins were extracted from sugarcane leaves, analyzed by 2D-PAGE and visualized by ImageMaster 2D Platinum software (Amersham Bioscience, Sweden). The results from 2D-PAGE were reproducible and showed qualitatively (presence/absence) identical protein patterns in both cultivars (data not shown) as 
described in Jangpromma et al. (2007). The numbers of proteins responding to water deficit in both cultivars were showed in Table 1.

Protein identification by mass spectrometry: The tryptic digested peptides were extracted from gels and analyzed by MALDI-TOF mass spectrometry. The obtained Peptide Mass Fingerprints (PMF) was compared with those from SWISS-PROT, NCBI and MSDB databases using the MASCOT program (http://www.matrixscience.com). Under drought stress, 128 protein spots showed a response to water deficit. Out of these proteins, 22 protein spots were identified by mass spectrometry (Fig. 1) (Jangpromma et al., 2007). The protein identification of drought response proteins including treatment effect and description is shown in Table 2. Two proteins which were expressed only in stressed K86-161, were identified as the protease inhibitor (spot 1) and similarity to replication protein A1 (spot 3). Fourteen proteins which were upregulated in stressed K86-161 when compared to control or well-watered plant are chalcone isomerase (spot 2), RuBisCO activase small isoform (spot 4), putative chelatase subunit (spot 5), anthocyanidin synthase (spot 6), S-adenosylmethionine decarboxylase proenzyme (spot 7), ferredoxin (spot 8), ATP synthase CF1 beta chain (spot 9), proteinase inhibitor type- $2 \mathrm{~K}$ precursor (spot 10), ubiquitin (spot 11) which contains $\mathrm{H}^{+}$-transporting two-sector ATPase (EC 3.6.3.14) beta chain (spot 12), ATP synthase alpha chain (spot 13), actin (spot 14), actin 8 (spot 17) and unidentified protein (spot 22). Other identified proteins were comparable intensity when compared to control are similar to NADP-dependent malic enzyme (spot 15), ferritin-1, chloroplast precursor (EC 1.16.3.1) (spot 16), ras-related protein Rab11C (spot 18), alpha-tubulin 5 (spot 19), proteinase inhibitor B precursor (spot 20) and thaumatin-like protein (spot 21).

Furthermore, These 22 protein spots were compared to stressed Khon Kaen 1, 12 proteins were up-regulated in stressed K86-161 (spot 1, 4, 5, 6, 7, 8, $9,13,15,16,17,22)$. Out of these proteins, 5 protein spots were down-regulated (spot 2, 3, 10, 11, 20) and 5 protein spots were comparable intensity (spot 12, 14, $18,19,21)$. The found drought stress up-regulates proteins in K86-161 cultivar such as protease inhibitor, RuBisCO activase isoform and ferredoxin are interesting. These proteins are likely to play a role in stabilizing, controlling proteolysis (Schwartz et al., 1995) and maintaining the function of the chloroplast during plant exposure to drought stress (Huo et al., 2004). When compared to control K86-161, the Protease inhibitor was only detected in stressed plant, thus this protein was induced by subsequent induction after stress treatment. On the other hand, the expression of RuBisCO activase small isoform and ferredoxin can detected in both stressed and control plants.

Table 1: Number of proteins responding to water deficit in K86-161 and Khon Kaen 1 sugarcane cultivars

\begin{tabular}{lll}
\hline & No. protein spots \\
& $\begin{array}{l}\text { K86-161 } \\
\text { cultivar }\end{array}$ & $\begin{array}{l}\text { Khon Kaen 1 } \\
\text { cultivar }\end{array}$ \\
Response & $>500$ & $>500$ \\
\hline Total protein spots & 128 & 104 \\
Response to water deficit & 46 & 42 \\
Up-regulated & 28 & 32 \\
Down-regulated & 54 & 30 \\
Only detected in response to water deficit & & \\
\hline
\end{tabular}

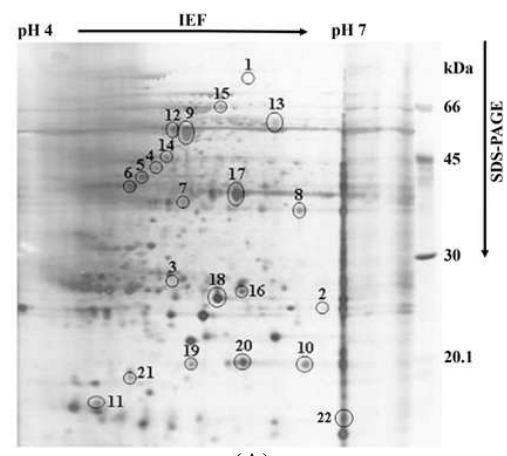

(A)

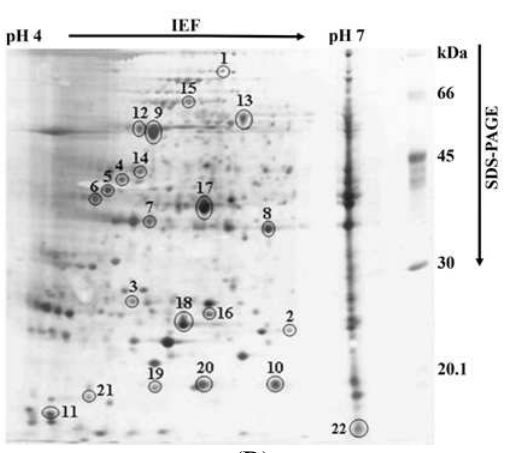

(B)

Fig. 1: 2-DE gel analysis of proteins extracted from control and drought-stressed K86-161 cultivar. In the first dimension (IEF), $250 \mu \mathrm{g}$ of protein was loaded on a $13 \mathrm{~cm}$ IPG strip with a linear gradient of $\mathrm{pH} 4-7$. The second dimension (SDS-PAGE), $15 \%$ polyacrylamide gel was used. Proteins were visualized by silver staining. The circles indicate spot proteins responding to drought by detected only in stressed K86-161 (spot 1 and 3), upregulated (spot 2, 4, 5, 6, 7, 8, 9, 10, 11, 12, 13, 14, 17, 22) and comparable level (spot 15, 16, 18, 19, 20, 21). These protein spots were selected for MALDI-TOF mass spectrometry. (A) Control K86-161; (B) stressed K86-161 
Am. J. Biochem. \& Biotech., 6 (2): 89-102, 2010

Table 2: Identification of proteins change in sugarcane leaf of cultivar K86-161 under drought stress by Peptide Mass Fingerprint (PMF)

\begin{tabular}{|c|c|c|c|c|c|c|c|c|}
\hline \multirow[b]{2}{*}{ Spot. No. } & \multicolumn{8}{|c|}{ Treatment effect } \\
\hline & $\begin{array}{l}\text { Compared } \\
\text { to control } \\
\text { K86-161 }\end{array}$ & $\begin{array}{l}\text { Compared } \\
\text { to stress } \\
\text { KK1 }\end{array}$ & Matched protein & $\begin{array}{l}\text { Theoretical } \\
\text { Mw/pI }\end{array}$ & $\begin{array}{l}\text { Experimental } \\
\mathrm{Mw} / \mathrm{pI}\end{array}$ & $\begin{array}{l}\text { Sequence } \\
\text { coverage }^{\mathrm{a}} \\
(\%)\end{array}$ & $\begin{array}{l}\text { Matched }^{b} \\
\text { protein }\end{array}$ & Species \\
\hline 1 & $\mathrm{P} / \mathrm{A}$ & $\uparrow$ & Protease inhibitor & $76.14 / 5.63$ & $82.02 / 5.94$ & 60 & 3 & Zea mays subsp. parviglumis \\
\hline 2 & $\uparrow$ & $\downarrow$ & Chalcone isomerase & $23.68 / 5.33$ & $24.54 / 6.53$ & 39 & 4 & $\begin{array}{l}\text { Hordeum vulgare subsp. } \\
\text { Vulgare }\end{array}$ \\
\hline 3 & $\mathrm{P} / \mathrm{A}$ & $\downarrow$ & Similarity to replication protein $\mathrm{A} 1$ & $31.75 / 5.91$ & $30.63 / 5.30$ & 41 & 6 & Arabidopsis thaliana \\
\hline 4 & $\uparrow$ & $\uparrow$ & RuBisCO activase small isoform & $47.90 / 5.85$ & $48.36 / 5.00$ & 24 & 6 & Oryza sativa \\
\hline 5 & $\uparrow$ & $\uparrow$ & Putative chelatase subunit & $45.13 / 5.50$ & $46.36 / 4.94$ & 19 & 4 & $\begin{array}{l}\text { Oryza sativa } \\
\text { (japonica cultivar group) }\end{array}$ \\
\hline 6 & $\uparrow$ & $\uparrow$ & Anthocyanidin synthase & $40.83 / 5.14$ & $44.85 / 4.88$ & 23 & 6 & $\begin{array}{l}\text { Brassica oleracea } \\
\text { var.capitata }\end{array}$ \\
\hline 7 & $\uparrow$ & $\uparrow$ & $\begin{array}{l}\text { S-adenosylmethionine decarboxylase } \\
\text { proenzyme }\end{array}$ & $39.68 / 4.99$ & $40.95 / 5.0$ & 16 & 4 & Vitis vinifera \\
\hline 8 & $\uparrow$ & $\uparrow$ & Ferredoxin & $40.83 / 7.00$ & $38.23 / 6.34$ & 24 & 6 & Zea mays \\
\hline 9 & $\uparrow$ & $\uparrow$ & ATP synthase CF1 beta chain & $53.93 / 5.31$ & $60.88 / 5.18$ & 38 & 13 & $\begin{array}{l}\text { Saccharumm hybrid cultivar } \\
\text { SP-80-3280 }\end{array}$ \\
\hline 10 & $\uparrow$ & $\downarrow$ & Proteinase inhibitor type- $2 \mathrm{~K}$ precursor & $16.49 / 6.67$ & $19.42 / 6.44$ & 27 & 4 & Solanum tuberosum \\
\hline 11 & $\uparrow$ & $\downarrow$ & Ubiquitin & $20.37 / 4.28$ & $18.78 / 4.70$ & 38 & 4 & Medicago truncatula \\
\hline 12 & $\uparrow$ & $=$ & $\begin{array}{l}\mathrm{H}^{+} \text {-transporting two-sector ATPase } \\
\text { (EC 3.6.3.14) beta chain }\end{array}$ & $54.00 / 5.31$ & $62.24 / 5.10$ & 34 & 11 & Zea mays \\
\hline 13 & $\uparrow$ & $\uparrow$ & ATP synthase alpha chain & $55.14 / 5.95$ & $63.66 / 6.05$ & 24 & 13 & $\begin{array}{l}\text { Oryza sativa } \\
\text { (japonica cultivar-group) }\end{array}$ \\
\hline 14 & $\uparrow$ & $=$ & Actin & $41.69 / 5.24$ & $50.28 / 5.14$ & 26 & 7 & Saccharumm Officinarum \\
\hline 15 & $=$ & $\uparrow$ & NADP-dependent malic enzyme & $69.33 / 6.23$ & $69.83 / 5.42$ & 17 & 7 & Sorghum bicolar \\
\hline 16 & $=$ & $\uparrow$ & $\begin{array}{l}\text { Ferritin-1, chloroplast precursor } \\
\text { (EC 1.16.3.1) }\end{array}$ & $28.60 / 6.14$ & $27.66 / 5.93$ & 26 & 3 & Pisum satiyum \\
\hline 17 & $\uparrow$ & $\uparrow$ & Actin 8 & $41.86 / 5.37$ & $43.65 / 5.85$ & 26 & 5 & Arabidopsis thaliana \\
\hline 18 & $=$ & $=$ & Ras-related protein Rab11C & $23.68 / 6.22$ & $24.42 / 5.68$ & 22 & 4 & Lotus japonicus \\
\hline 19 & $=$ & $=$ & Alpha-tubulin & $521.68 / 4.99$ & $20.65 / 5.52$ & 37 & 4 & $\begin{array}{l}\text { Hordeum vulgare } \\
\text { subsp. vulgare }\end{array}$ \\
\hline 20 & $=$ & $\downarrow$ & Proteinase inhibitor B precursor & $19.16 / 5.76$ & $20.41 / 5.97$ & 26 & 4 & Sagittaria sagittifolia \\
\hline 21 & $=$ & $=$ & Thaumatin-like protein & $22.06 / 4.90$ & $20.37 / 5.00$ & 48 & 7 & Daucus carota (Carrot) \\
\hline 22 & $\uparrow$ & $\uparrow$ & - & - & $18.00 / 7.00$ & - & - & - \\
\hline
\end{tabular}

${ }^{a}$ : Percentage of coverage between the amino acids present in PMF and the sequences in the database; ${ }^{b}:$ Number of peptides matched; KK1: Cultivar Khon Kaen 1; $\uparrow:$ Increased proteins in stressed cultivar K86-161; $\downarrow$ : Decreased proteins in stressed cultivar K86-161; P/A: Present in stressed plants but absent in controls; =: Comparable intensity of protein

For that reason, this protein was detected to tolerance cultivars. The result confirming cultivar K86-161 has better drought tolerance and adaptations to help them survive than the Khon Kaen 1 sugarcane cultivar.

Based on database search, most of the major drought-induced proteins were related to the cellular process and metabolism, which indicates the adaptation or maintenance of sugarcane under water deficit. Protein spot 1 obtained highest sequence coverage with peptide mass search. Another criterion for the quality of a peptide mass fingerprint is the number of matched peptides. The total number of matched peptides of all spots was different. Particularly, spots 9, 12 and 13 obtained a high number of matched peptides at 13, 11 and 13 , respectively.

For p18 (spot 22), the mass spectrum of digested p18 is shown in Fig. 2. The result from searching revealed that no matching data and hence corresponding proteins were found from these databases. However, p18 exhibited a significant homology to the large molecular weight protein, rice hypothetical protein OsI_014484, which has unidentified function. The sequence coverage was 17\% identity to OsI_014484 (pI of 8.34 and molecular weight of $34.127 \mathrm{kDa}$ ). Fifty-six amino acid residues of p18 matched to part of the OsI_014484 sequence comprising mainly hydrophilic residues. The total percentage of hydrophilic residues in p18 is 50\%, such as Lys (14.3\%), Ser (14.3\%), Glu (5.4\%) and Arg $(3.6 \%)$.

p18 was further characterized by the TagIdent program (www.expasy.org) using $\mathrm{Mw} 18 \mathrm{kDa}$ and $\mathrm{pI} 7$ according to the data from 2D-PAGE. This program generates a list of proteins in which $\mathrm{pI}$ and $\mathrm{Mw}$ are close to the given information. The results showed that 37 proteins in the UniProtKB/Swiss-Prot database have $\mathrm{pI} / \mathrm{Mw}$ close to those of $\mathrm{p} 18$. Among these, 4 groups of proteins have been found in the result from Peptide Mass Fingerprint (PMF) search as well. They are: class I heat shock protein (Chain: 1-159, pI: 6.93, Mw: $18.033 \mathrm{kDa}$ ), dehydrin Rab18 (Chain: 1-186, pI: 7.11, Mw: $18.464 \mathrm{kDa})$ and late embryogenesis abundant protein D-7 (Chain: 1-136, pI: 6.93, Mw: $14.614 \mathrm{kDa}$ ). 
Am. J. Biochem. \& Biotech., 6 (2): 89-102, 2010

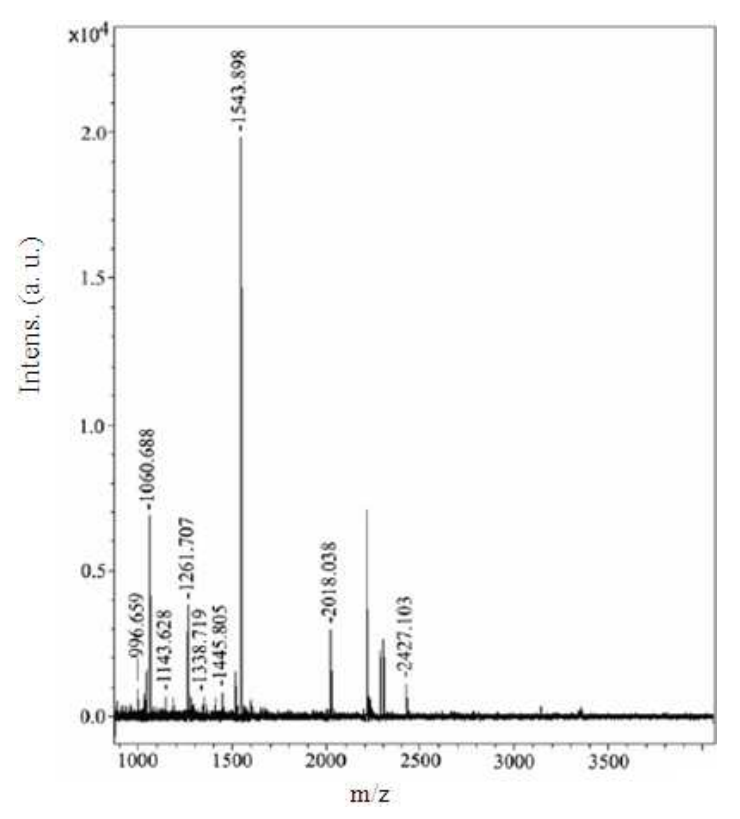

Fig. 2: MALDI-TOF mass spectrum of the p18 from 2D-PAGE

Immunochemical detection of p18 in drought tolerant sugarcane cultivars: From previous study (Jangpromma et al., 2007) we found that the band of p18 from K86-161 has higher intensity than that of Khon Kaen 1 with the high specificity. To confirming the specificity of p18-antiserum, the western blotting analysis of 2D-PAGE protein profiles was performed. The result coincides with the western blotting analysis of SDS-PAGE as described in Fig. 3.

To verify the specificity of the anti-p18 antibody, this antibody was used to probe other drought-tolerant sugarcane cultivars using 2D-PAGE following western blotting. Four types of cultivars were taken from Khon Kaen Field Crop Research Center in Khon Kaen Province, Northeast of Thailand. These cultivars are classified as susceptible or tolerant to drought by phenotypic appearances. The drought-tolerant sugarcane cultivars were K88-92 and Uthong 1, while the drought-susceptible sugarcane cultivars were Phill.66-07 and K84-200. Plant samples were grown in the field under natural drought conditions. Western blotting results demonstrated that anti-p18 antibody was able to specifically bind to p18 in all four cultivars, with stronger signal in K88-92. Uthong 1, while classified as drought-tolerant, exhibited the level of signal comparable to the other two drought-susceptible cultivars (Fig. 4). The result from ELISA shows that p18 in all cultivars displayed high specificity to antip18 antibody, with higher level in drought-tolerant types (Fig. 5).
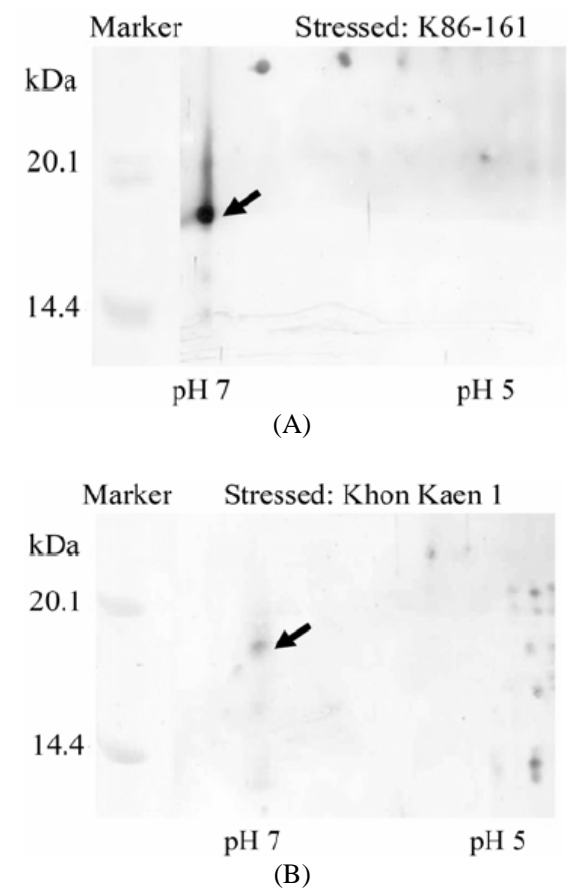

Fig. 3: Comparison of p18 accumulations in two unrelated sugarcane cultivars (K86-161 and Khon Kaen 1) under drought stress conditions using anti-p18 antibody (dilution of antiserum, 1:100). Proteins were separated by 2D-PAGE. In the First dimension (IEF), $100 \mu \mathrm{g}$ of protein was loaded on a $7 \mathrm{~cm}$ IPG strip with a linear gradient of $\mathrm{pH} 4-7$. In the second dimension (SDS-PAGE), $15 \%$ polyacrylamide gel was used. (A) Drought stressed K86-161 and (B) drought stressed Khon Kaen 1. The arrows point to $\mathrm{p} 18$ position

Physiological indexes in drought tolerance: In this study, total chlorophyll, chlorophyll a and chlorophyll b contents and Superoxide Dismutase (SOD) were determined to compare between drought-tolerant and drought-susceptible cultivars. The results in Table 3 show that the overall chlorophyll contents are higher in drought-tolerant cultivars except Khon Kaen 1, has highest chlorophyll content (Chl t: $18.32 \mu \mathrm{g} \mathrm{mL}^{-1}$ ).

In our study, the Table 3 shows that SOD activity of drought-tolerant plants is higher than that of droughtsusceptible plants, with 168.4, 141.2 and 129.6 activity $\mathrm{mg}^{-1}$ in K86-161, K88-92 and Uthong 1, respectively (Table 3). These results are in agreement with other reports (Spychalla and Desborough, 1990; Davies, 1987), showing that drought-tolerant sugarcane expresses a high level of SOD to destroy ROS from stress. 
Am. J. Biochem. \& Biotech., 6 (2): 89-102, 2010

Table 3: Physiological indexes in sugarcane plants

\begin{tabular}{|c|c|c|c|c|c|c|}
\hline \multirow[b]{2}{*}{ Physiological indexes } & \multicolumn{3}{|c|}{ Drought tolerance cultivars } & \multicolumn{3}{|c|}{ Drought-susceptible cultivars } \\
\hline & K86-161 & K88-92 & Uthong 1 & Khon Kaen 1 & Phill.66-07 & K84-200 \\
\hline \multicolumn{7}{|l|}{ Content of chlorophyll $\left(\mu \mathrm{g} \mathrm{mL} \mathrm{L}^{-1}\right)$} \\
\hline Chlorophyll a & $9.44 \pm 2.0$ & $7.32 \pm 1.0$ & $5.68 \pm 1.9$ & $14.12 \pm 8.2$ & $4.50 \pm 2.5$ & $4.36 \pm 0.5$ \\
\hline Chlorophyll b & $2.84 \pm 0.5$ & $2.32 \pm 0.1$ & $1.88 \pm 0.6$ & $4.20 \pm 2.6$ & $1.52 \pm 0.9$ & $1.44 \pm 0.4$ \\
\hline Total chlorophyll & $12.28 \pm 2.5$ & $9.68 \pm 1.0$ & $7.52 \pm 2.5$ & $18.32 \pm 10.8$ & $6.04 \pm 3.4$ & $5.80 \pm 0.7$ \\
\hline \multicolumn{7}{|l|}{ Activity of enzyme (activity $\mathbf{m g}^{-1}$ ) } \\
\hline Activity of SOD & $168.40 \pm 9.5$ & $141.20 \pm 17.8$ & $129.60 \pm 14.7$ & $76.25 \pm 6.9$ & $128.00 \pm 13.3$ & $113.10 \pm 19.1$ \\
\hline
\end{tabular}

The data were averaged three times

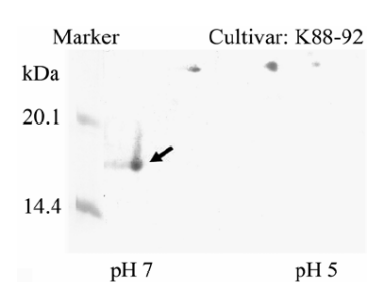

(A)

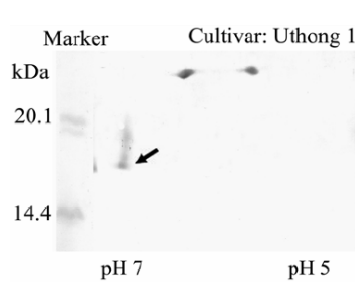

(B)

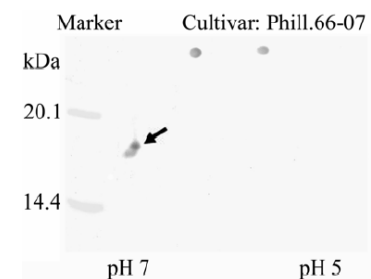

(C)

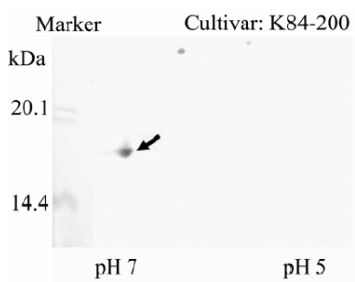

(D)

Fig. 4: Western blotting analysis of crude protein extracts from sugarcane leaves using the polyclonal antibody raised against p18 (dilution of antiserum, 1:100). Proteins were extracted from leaf and separated by 2DPAGE. In the First dimension (IEF), $125 \mu \mathrm{g}$ of protein was loaded on a $7 \mathrm{~cm}$ IPG strip with a linear gradient of $\mathrm{pH}$ 4-7. In the Second Dimension (SDS-PAGE), 15\% polyacrylamide gel was used. The spots were visualized by alkaline phosphatase reaction. (A) The drought tolerant sugarcane is K88-92 (B) Uthong 1 cultivar (C) The drought-susceptible sugarcane is Phill.66-07 (D) K84-200 cultivar

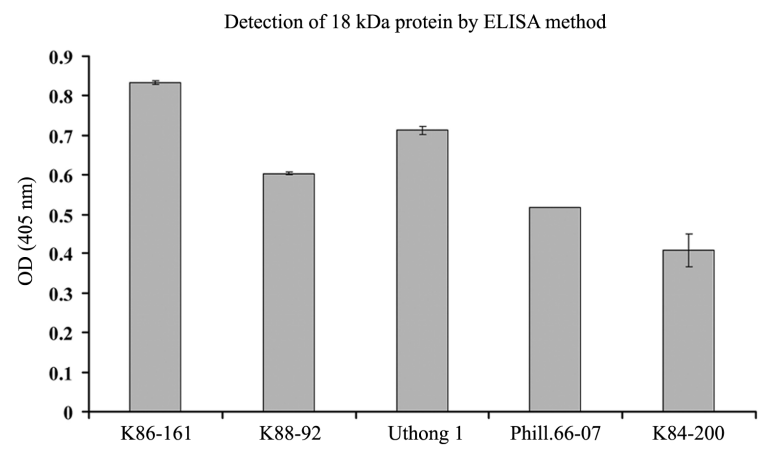

Fig. 5: ELISA analysis of protein extracts from sugarcane leaves: each of five cultivars was coated on a 96-well micro titer-plate then tested with polyclonal antibody raised against p18. Dilution of antiserum for this experiment was $1: 100$. The test was done in triplicate and normal mouse serum was used as negative control

\section{DISCUSSION}

Water stress is a common phenomenon found in dryland crops including sugarcane, making them produce low yields. The selection of stress-tolerant cultivars for breeding programs is therefore necessary to find the crops suitable for dryland. Marker-Aided Selection (MAS) is one possibility for increasing drought and salt tolerance in dryland plants (Salekdeh et al., 2002). Biochemical markers relating to drought tolerance have become a popular tool in plant genetics. These markers were initially utilized in sugarcane (Ramagopal, 1990). Proteins or secondary metabolites from leaves are often used as markers due to feasible extraction processes. In this study, biomarkers associated with drought stress in sugarcane cultivars have been investigated. After water-deficit treatment, the K86-161 cultivar showed normal growth and RWC decreased slightly. Whereas, the RWC of Khon Kaen 1 cultivar showed lower than 70\%. This stress could be considered severe for sugarcane plants since RWC levels lower than $70 \%$ are known to induce marked damage.

Proteins responsive under water deficit are involved in numerous biological processes, such as antioxidant activity, signal transduction, photosynthesis, protein degradation, plant defense proteins and lipid metabolism. NADP-dependent malic enzyme and ferredoxin were noticed previously as drought-induced proteins, while other proteins, such as ferritin-1 was newly identified in response to drought stress for sugarcane. The possible role of these identified novel proteins in response to drought stress is now discussed. 
Protease Inhibitors (PIs) are important to survival of plant cells by water deficit. The function of the inhibitors is to control proteolysis within cells and organelles of fluids when limited proteolysis is important for the biochemical or physiological process (Schwartz et al., 1995; Ussuf et al., 2001). In lupin stem, protease inhibitor responded to water deficit (Pinheiro et al., 2005). In this study, the matched peptides from mascot search were used to compare with UniProt Knowledgebase, to predict the type of proteinase inhibitor using the fasta program. Database searches indicated that proteinase inhibitor B precursor showed homology to a partial serine proteinase inhibitor. That appears to be the largest family of proteinase. Reports on serine proteinase inhibitor which occurs in Solanaceae plants, show that it could play endogenous roles in environmental responses and development (Huang et al., 2007).

NADP-dependent malic enzyme is found in some $\mathrm{C} 4$ plants such as maize, sugarcane, sorghum and $\mathrm{C} 4$ Flaveria species, where it is used for the decaboxylation of malate in bundle sheath chloroplast; the $\mathrm{CO}_{2}$ produced is then fixed by $\mathrm{RuBisCO}$ (Drincovich et al., 2001). When stomata are open, malate are present at high concentrations in guard cells. In tobacco, NADP-dependent malic enzyme is located in guard cells and the cells around them may facilitate malate degradation during stomatal closure (Outlaw et al., 1981). Recent studies have also shown a manipulation of organic anion metabolisms in guard cells using NADP-dependent malic enzyme which may have developed as a practical mechanism for drought avoidance and water conservation during irrigation (Laporte et al., 2002). Therefore this enzyme is a specific function for drought tolerance in sugarcane.

$\mathrm{S}$-Adenosylmethionine Decarboxylase (SAM) is a widespread compound required in various methylation reactions, particularly for the methylation of several derivatives of the phenylpropanoid pathway. Other researchers have correlated SAM with drought stress, suggesting that polyamine biosynthesis is important in plant responses to drought stress ( $\mathrm{Li}$ and Chen, 2000). Spermine and spermidine, two polyamines in the SAM pathway, were found to induce elongation growth, increase photosynthetic capacityand reduce membrane leakage in drought stressed jack pine (Pinus banksiana) (Rajasekaran and Blake, 1999), pointing to a direct role of polyamines in cellular responses to drought stress.

Ribulose-1,5-Bisphosphate Carboxylase (RuBisCO) is a key enzyme in plant photosynthesis by combining atmospheric $\mathrm{CO}_{2}$ with Ribulose-1,5-Bisphosphate (RuBP) to form 3-phosphoglyceric acid. RuBisCO and
$\mathrm{H}^{+}$-transporting two-sector ATPase (EC 3.6.3.14) beta chains are likely to play a crucial role in maintaining the function of the chloroplast and the whole cells when the plant is under stress (Huo et al., 2004). In this study, RuBisCO subunit was detected upregulated in drought stressed but RuBisCo content was down-regulated in rice as a result of drought stress (Ali and Komatsu, 2006; Parry et al., 2002).

Ferredoxins (Fds) in plants are involved in photosynthesis. The role of this protein is to transfer electrons from Photoreduced Photosystem I (PS I) to Ferredoxin $\mathrm{NADP}^{+}$oxidoreductase (FNR), where NADPH is produced to serve $\mathrm{CO}_{2}$ assimilation (Fukuyama, 2004). In other reports, Fd functions to distribute electrons produced by the photoreduced PS I to several ferredoxin-dependent enzymes for nitrogen and sulfur assimilation (Knaff and Hirasawa, 1991).

Ferritin is an iron storage protein, involved in iron homeostasis in plant and animal cells. The function of this protein could play an important role in protecting cells against the most noxious Reactive Oxygen Species (ROS) known, the hydroxyl radicals, whose production is catalyzed by $\mathrm{Fe}$ (II) and (III) (Murgiaa et al., 2001). The ability of the leaves to store iron in the chloroplasts in a soluble readily available and nontoxic from is provided by ferritin. The ferritin gene induced by iron stress is also induced by drought and ABA (Fobis-Loisy et al., 1995).

Five proteins, up-regulated in drought stress plants are ATP synthase alpha chain, actin, actin 8 , similarity to replication protein $\mathrm{A} 1$ and ubiquitin.

Actin and actin 8 were detected only in droughttolerant cultivars and were increased by drought stress suggesting that these proteins might be required for osmoregulation under osmotic stress. Indeed, osmotic stress regulation of actin organization correlates well with $\mathrm{K}^{+}$channel activity in guard cells (Luan, 2002). Depolymerization of actin filaments by osmotic stress potentiates the inward $\mathrm{K}^{+}$current in guard cells. Therefore, actin filaments may serve as an osmosenser and target inward $\mathrm{K}^{+}$channels in guard cells for regulation.

During early drought in Alabidopsis, there is an increase in levels of mRNA encoding ubiquitin extension protein (Kiyosue et al., 1994), a fusion protein from which active ubiquitin is derived by proteolytic processing. This increase may be significant in terms of protein degradation, because ubiquitin has a role in tagging proteins for destruction (Ingram and Bartels, 1996). Other reported function of ubiquitin is thought to be required for protein turnover and recycling of amino acids (Yamaguchi-Shinozaki et al., 2002). 
The majority of identified proteins involved in drought stress of sugarcane is a group of proteins involved in photosynthesis; ATP synthase CF1 beta chain, ATP syntase alpha chain, RuBisCO activase small isoform, ferredoxin and ferritin-1. Water-stress is one of the most important environmental factors inhibiting photosynthesis (Bradford and Hsiao, 1982). Many studies have shown that decreases in photosynthesis resulting from water-stress can be associated with the perturbations of the biochemical processes of that pathway (Lauer and Boyer, 1992). The result shows that ATP synthase alpha chain was detected in both conditions of study (control and drought stress conditions). This protein is likely to play a crucial role in maintaining the function of the chloroplast and whole cells when the plant was drought stressed. The result indicated that ATP synthase alpha chain is the protein which persistently responds to drought. The chloroplast ATP synthase was up-regulated by drought stress in Plalaenopsis (Ali et al., 2005). Moreover, all of these proteins showed a response under drought conditions, indicating that these proteins are highly correlated with the water deficit.

Other identified proteins induced upon progressive dehydration are similar to replication protein A1, chalcone isomerase and alpha-tubulin 5, in which the definite function in stress response remains unclear. Protein expression from the two conditions of sugarcane growth showed more differenence in their proteins. However, they have similarity of proteins in basic mechanisms such as photosynthesis (ATP synthase).

For p18, the result from MALDI-TOF mass spectrum indicated that this protein is may be the hydrophilic protein. Normally, Charged or hydrophilic residues are found on the surface of the protein molecule. They are assumed to interact with water and other polar biological molecules through hydrogen bonding. Many studies have reported up-regulation of hydrophilic proteins under drought stress. For example, Ingram and Bartels (1996) found that the abundance of charged amino acids in Late Embryogenesis Abundant proteins (LEA proteins) resulted in highly hydrophilic polypeptides. The hydrophilic characteristic of LEA proteins may help protect specific cellular structures or ameliorate the effect of dryness during embryogenesis through attracting water or other polar molecules. Likewise, Wang et al. (2006) have reported that LEA proteins are the members of a large group of hydrophilic proteins. Their mechanism of function could be fulfilled through: Maintaining protein or membrane structure, sequestration of ions, binding of water, or operation as molecular chaperones to help prevent the formation of damaging protein aggregates. From such an advantageous structure of LEA proteins, LEA genes have been transferred into a number of plant species to improve tolerance to drought or salt. The expression of LEA genes in transgenic rice and wheat has been shown to confer tolerance to salt and drought stress or to increase efficiency in water usage and biomass productivity. Moreover, the similar results from PMF and TagIdent suggest that p18 may be a member of the hydrophilic proteins, which include, but are not limited to, rice hypothetical protein OsI_014484, LEA proteins or Dehydrin Rab18. Dehydrins are known as Group II Late Embryogenesis Abundant (LEA) proteins. Large hydrophilicity and thermostability of dehydrins suggest that these proteins may stabilize the protein structure through detergent-and chaperone-like properties. They are localized in nucleus, cytoplasm and plasma membrane (Borovskii et al., 2002). Alternatively, p18 may be a member of stress-inducible heat shock proteins since its level was up-regulated under drought condition. Similar results but in other plant species have been shown in the report by Wechsberg et al. (1994). The $18-, 28-, 31-\mathrm{kDa}$ dehydrin-like proteins in crowfoot seeds (Ranunculus sceleratus L.) were accumulated depending on the extent of water stress. Another study in bromegrass (Bromus inermis Leyss) has shown that the expression of polypeptide with molecular mass of $18.08 \mathrm{kDa}$ and isoelectric point at 7.50 was induced by abscisic acid through cold or drought stress (Wu et al., 2005). Regarding our finding, p18 induced under water deficit could play a role similar to those mentioned above. Further investigation regarding the structure and function of p18 is required to elucidate its role under drought stress conditions. Therefore, this protein was used to produce antibody to further analysis.

The results from western blotting analysis in Fig. 3 indicate high specificity of antiserum to $\mathrm{p} 18$. The band of p18 from K86-161 has higher intensity than that of Khon Kaen 1, in equivalent protein amount. The lower binding of p18-antiresum in Khon Kaen 1 might come from different conformation between p18 from this cultivar and that from K86-161, leading to differential binding capacity. Taken together, p18 has potential as a biomarker candidate for developing screening techniques for drought-tolerant sugarcane cultivars.

To confirm the association of p18 and drought tolerance again, anti-p18 antibody was used to analyze additional 4 sugarcane cultivars that showed high strong expression in drought tolerance cultivar (K8892), whereas Uthong 1 showed comparable level. This indistinguishable result might be from the limited 
sensitivity of the western blotting method. Therefore, ELISA was performed to increase the sensitivity.

Photosynthesis is an essential process to maintain crop growth and development. Photosynthetic systems in higher plants have been reported to be mostly sensitive to drought stress (Rong-Hua et al., 2006). This response might result from an inhibition of electron transport activity, leading to a decrease in generation of reducing power or metabolic activity (Guo and AlKhatib, 2003). Measurement of photosynthetic parameters such as chlorophyll content might reflect the influences of photosynthetic indexes are closely correlated with the rate of carbon exchange. Therefore, they might be used to evaluate energetic/metabolic imbalance in photosynthesis or yield performance among genotypes under water deficit (Araus et al., 1998). Chlorophyll is one of the major chloroplast components in photosynthesis. Relative chlorophyll content corresponds to photosynthetic rate. It has been argued whether high chlorophyll content (i.e., stay green trait) could contribute to yield maintenance under drought conditions (Rong-Hua et al., 2006). Many studies have indicated that, under water-limited conditions, staying green results in an efficiency in transpiration and yield production in sorghum, maize and wheat (Benbella and Paulsen, 1998; Borrell et al., 2000; Haussmann et al., 2002). In this study, our result showed that two physiological index; Chlorophyll content and SOD are higher in drought tolerance sugarcane cultivars except the chlorophyll content of Khon Kaen 1 (droughtsusceptible) that showed higher. The difference of the chlorophyll levels between these two groups of cultivars suggests that they respond to drought to different extent. The components of the photosynthetic apparatus could be more damaged in drought susceptible than that in drought tolerance genotypes, reflecting their differential mechanism of protection. It might be possible that the genetic components in drought tolerant cultivars allow the photosynthetic process to have higher tolerance to drought stress.

Normal cellular metabolism is interrupted under environmental stresses such as drought, excessive light, temperature extremes, air pollution, wounding, or herbicides. The imbalanced metabolism results in the production of oxygen free radicals. Expression of Superoxide Dismutase (SOD) is a common response to restore the balance of cells (Zang and Komatsu, 2007). Within a cell, SOD acts as the first line of defense environmental stress on plant growth and yield. The against Reactive Oxygen Species (ROS) $\mathrm{O}_{2}{ }^{--}$, a highly toxic oxidant, is produced at electron transport compartments, including mitochondria, chloroplasts, microsomes, glyoxysomes, perxisomes, apoplasts and cytosol (Alscher et al., 2002). It is therefore crucial that SOD must be present in the compartments for removal of $\mathrm{O}_{2}{ }^{--}$(Takahashi and Asada, 1983).

\section{CONCLUSION}

In summary, our results demonstrate that droughttolerant sugarcane plants can better adapt to water deficit compared with drought-susceptible cultivars. Most proteins associated with drought related to many metabolism processes in cell such as photosynthesis and plant defense. These results indicate that sugarcane responds to drought by complex metabolism pathways. Drought-associated indexes have higher chlorophyll contents and higher SOD activity. In addition, the high expression level of p18 in drought-tolerant cultivars may be used as a biomarker for agronomic traits in traditional breeding programs.

\section{ACKNOWLEDGEMENT}

This research was supported by the Center of Excellence on Agricultural Biotechnology, Science and Technology Postgraduate Education and Research Development Office (PERDO), Commission on Higher Education, Ministry of Education and Agricultural Biotechnology Research Center for Sustainable Economy, Khon Kaen University, The grant from under the program Strategic Scholarships for Frontier Research Network for the Ph.D. Program Thai Doctoral degree from the Office of the Higher Education Commission, Thailand, The Innovation Potential Research Proposal for High Social Impact Scholarship and Department of Biochemistry, Faculty of Science, Khon Kaen University. We are most grateful to $\mathrm{Mr}$. Werapon Ponragdee, Khon Kaen Field Crop Research Center for providing sugarcane cultivars. The authors thank Mr. Ian Thomas, Department of Physics, Faculty of Science, Khon Kaen University for critical review of the manuscript.

\section{REFERENCES}

Ali, G.M. and S. Komatsu, 2006. Proteomic analysis of rice leaf sheath during drought stress. J. Proteome. Res., 5: 396-403. DOI: 10.1021/pr050291g

Ali, M.B., E.J. Hahn and K.Y. Paek, 2005. Effects of temperature on oxidative stress defense systems, lipid peroxidation and lipoxygenase activity in Phalaenopsis. Plant Physiol. Biochem., 43: 213-223. DOI: 10.1016/j.plaphy.2005.01.007

Alscher, R.G., N. Erturk and L.S. Heath, 2002. Role of Superoxide Dismutases (SODs) in controlling oxidative stress in plants. J. Exp. Bot., 53: 1331-1341. PMID: 11997379 
Araus, J.L., T. Amaro, J. Voltas, H. Nakkoul and M.M. Nachit, 1998. Chlorophyll fluorescence as a selection criterion for grain yield in durum wheat under Mediterranean conditions. Field. Crop. Res., 55: 209-223. DOI: 10.1016/S0378-4290(97)00079-8

Barrs, H.D. and P.E. Weatherley, 1962. A reexamination of the relative turgidity techniques for estimating water deficits in leaves. Aust. J. Biol. Sci., 15: 413-428.

Benbella, M. and G.M. Paulsen, 1998. Efficacy of treatments for delaying senescence of wheat leaves: 2. Senescence and grain yield under field conditions. Agron. J., 90: 332-338. http://agron.scijournals.org/cgi/reprint/90/3/332

Borovskii, G.B., I.V. Stupnikova, A.I. Antipina, S.V. Vladimirova and V.K. Voinikov, 2002. Accumulation of dehydrin-like proteins in the mitochondria of cereals in response to cold, freezing, drought and ABA treatment. BMC Plant Biol., 2: 1-7. DOI: 10.1186/1471-2229-2-5

Borrell, A.K., G.L. Hammer and R.G. Henzell, 2000. Does maintaining green leaf area in sorghum improve yield under drought? II. Dry matter production and yield. Crop Sci., 40: 1037-1048. http://cat.inist.fr/?aModele $=$ afficheN\&cpsidt $=1490587$

Bradford, K.J. and T.C. Hsiao, 1982. Stomatal behavior and water relations of waterlogged tomato plants. Plant Physiol., 70: 1508-1513. http://www.plantphysiol.org/cgi/content/abstract/7 $0 / 5 / 1508$

Bradford, M.M., 1976. A rapid and sensitive method for the quantitation of microgram quantities of protein utilizing the principle of protein-dye binding. Anal. Biochem., 72: 248-254. PMID: 942051

Bray, E.A., 1997. Plant responses to water deficit. Trends Plant Sci., 2: 48-54. DOI: 10.1016/S13601385(97)82562-9

Davies, K.J.A., 1987. Protein damage and degradation by oxygen radicals. I. General aspects. J. Biol. Chem., 262: 9895-9901. http://www.jbc.org/content/262/20/9895.full.pdf+html

Drincovich, M.F., P. Casati and C.S. Andreo, 2001. NADP-malic enzyme from plants: A ubiquitous enzyme involved in different metabolic pathways. FEBS Lett., 490: 1-6. PMID: 11172800

Fobis-Loisy, I., K. Loridon, S. Lobreaux, M. Lebrun and J.F. Briat, 1995. Structure and differential expression of two maize ferritin genes in response to iron and abscisic acid. Eur. J. Biochem., 231: 609-619. PMID: 7649160

Fukuyama, K., 2004. Structure and function of planttype ferredoxins. Photosynth. Res., 81: 289-301. PMID: 16034533
Guo, P. and K. Al-Khatib, 2003. Temperature effects on germination and growth of redroot pigweed (Amaranthus retroflexus), Palmer amaranth (A. palmeri) and common waterhemp (A. rudis). Weed. Sci., 51: 869-875. DOI: 10.1614/P2002-127

Haussmann, B., V. Mahalakshmi, B.V.S. Reddy, N. Seetharama and C. Hash et al., 2002. QTL mapping of stay-green in two sorghum recombinant inbred populations. Theor. Applied Genet., 106: 133-142. DOI: 10.1007/s00122-0021012-3

Hogarth, D.M., 1987. Genetics of Sugarcane. In: Sugarcane Improvement Though Breeding, Heinz, D.J. (Ed.). Elsevier, Amsterdam, ISBN: 0444427694, pp: 255-271.

Huang, Y., B. Xiao and L. Xiong, 2007. Characterization of a stress responsive proteinase inhibitor gene with positive effect in improving drought resistance in rice. Planta, 226: 73-85. DOI: 10.1007/s00425-006-0469-8

Huo, C.M., B.C. Zhao, R.C. Ge, Y.Z. Shen and Z.J. Huang, 2004. Proteomic analysis of the salt tolerance mutant of wheat under salt stress. Yi Chuan Xue Bao, 31: 1408-1414. PMID: 15633648

Ingram, J. and D. Bartels, 1996. The molecular basis of dehydration tolerance in plants. Annu. Rev. Plant Physiol. Plant Mol. Biol., 47: 377-403. DOI: 10.1146/annurev.arplant.47.1.377

Jangpromma, N., S. Kitthaisong, S. Daduang, P. Jaisil and S. Thammasirirak, 2007. $18 \mathrm{kDa}$ protein accumulation in sugarcane leaves under drought stress conditions. KMITL Sci. Tech. J., 7: 44-54. http://www.kmitl.ac.th/ejkmitl/vol7nos1/P07.pdf

Jiang, Y. and B. Huang, 2002. Protein alterations in tall fescue in response to drought stress and abscisic acid. Crop. Sci., 42: 202-207. http://crop.scijournals.org/cgi/reprint/42/1/202

Kiyosue, T., K. Yamaguchi-Shinozaki and K. Shinozaki, 1994. Cloning of cDNAs for genes that are Earlyresponsive to Dehydration stress (ERDs) in Arabidopsis thaliana L.: Identification of three ERDs as HSP cognate genes. Plant Mol. Biol., 25: 791-798. DOI: 10.1007/BF00028874

Knaff, D.B. and M. Hirasawa, 1991. Ferredoxindependent chloroplast enzymes. Biochim. Biophys. Acta, 1056: 93-125. PMID: 1671559

Laporte, M.M., B. Shen and M.C. Tarczynski, 2002. Engineering for drought avoidance: expression of maize NADP-malic enzyme in tobacco results in altered stomatal function. J. Exp. Bot., 53: 699-705. http://jxb.oxfordjournals.org/cgi/reprint/53/369/699 
Lauer, M.J. and J.S. Boyer, 1992. Internal $\mathrm{CO}_{2}$ measured directly in leaves: Abscisic acid and low leaf water potential cause opposing effects. Plant Physiol., 98: 1310-1316.

http://www.plantphysiol.org/cgi/reprint/98/4/1310

Li, Z.Y. and S.Y. Chen, 2000. Differential accumulation of the $\mathrm{S}$-adenosylmethionine decarboxylase transcript in rice seedlings in response to salt and drought stresses. Theor. Applied Genet., 100: 782-788. DOI: 10.1007/s001220051352

Lopez, C.G., G. Banowetz, C.J. Peterson and W.E. Kronstad, 2001. Differential accumulation of a 24$\mathrm{kd}$ dehydrin protein in wheat seedlings correlates with drought stress tolerance at grain filling. Hereditas, 135: 175-181. PMID: 12152331

Luan, S., 2002. Signaling drought in guard cells. Plant Cell Environ., 25: 229-237. PMID: 11841666

Moran, R., 1982. Formulae for determination of chlorophyllous pigments extracted with $\mathrm{N}, \mathrm{N}$ Dimethylformamide. Plant Physiol., 69: 1376-1381. http://www.ncbi.nlm.nih.gov/pmc/articles/PMC426422/

Murgiaa, I., J.F. Briatb, D. Tarantinoa and C. Soavea, 2001. Plant ferritin accumulates in response to photoinhibition but its ectopic overexpression does not protect against photoinhibition. Plant Physiol. Biochem., 39: 797-805. DOI: 10.1016/S09819428(01)01297-9

O'Farrell, P.H., 1975. High resolution two-dimensional electrophoresis of proteins. J. Biol. Chem., 250: 4007-4021. PMID: 236308

Outlaw, W.H., J. Manchester and P.H. Brown, 1981. High levels of malic enzyme activities in Vicia faba L. epidermal tissue. Plant Physiol., 68: 1047-1051. PMID: 16662049

Parry, M.A.J., P.J. Andralojc, S. Khan, P.J. Lea and A.J. Keys, 2002. Rubisco activity: Effects of drought stress. Ann. Bot. (Lond), 89: 833-839. http://aob.oxfordjournals.org/cgi/reprint/89/7/833

Pinheiro, C., J. Kehr and C.P. Ricardo, 2005. Effect of water stress on lupin stem protein analyzed by twodimensional gel electrophoresis. Planta, 221: 716-728. PMID: 15668768

Rajasekaran, L.R. and T.J. Blake, 1999. New plant growth regulators protect photosynthesis and enhance growth under drought of jack pine seedlings. J. Plant Growth Regul., 18: 175-181. PMID: 10688707

Ramagopal, S., 1990. Protein polymorphism in sugarcane revealed by two-dimensional gel analysis. Theor. Applied Genet., 79: 297-304. DOI: 10.1007/BF01186071
Rhodes, D. and A.D. Hanson, 1993. Quaternary ammonium and tertiary sulfonium compounds in higher plants. Annu. Rev. Plant Physiol. Plant Mol. Biol., 44: 357-384. DOI: 10.1146/annurev.pp.44.060193.002041

Riccardi, F., P. Gazeau, D. de Vienne and M. Zivy, 1998. Protein changes in response to progressive water deficit in maize. Quantitative variation and polypeptide identification. Plant Physiol., 117: 1253-1263. http://www.plantphysiol.org/cgi/reprint/117/4/1253

Rong-Hua, L.I., G.U.O. Pei-Guo, M. Baumz, S. Grando and S. Ceccarelli, 2006. Evaluation of chlorophyll content and fluorescence parameters as indicators of drought tolerance in barley. Agric. Sci. China, 10: 751-757. DOI: 10.1016/S1671-2927(06)60120-X

Salekdeh, G.H., J. Siopongco, L.J. Wade, B. Ghareyazie and J. Bennett, 2002. A proteomics approach to analyzing drought-and salt-responsiveness in rice. Field Crop Res., 76: 199-219. DOI: 10.1016/S0378-4290(02)00040-0

Schwartz, A., N. Ilan, M. Schwarz, J. Scheaffer and S.M. Assmann et al., 1995. Anion-channel blockers inhibit s-type anion channels and abscisic acid responses in guard cells. Plant Physiol., 109: 651-658. PMID: 12228619

Seki, M., A. Kamei, K. Yamaguchi-Shinozaki and K. Shinozaki, 2003. Molecular responses to drought, salinity and frost: common and different paths for plant protection. Curr. Opin. Biotechnol., 14: 194-199. PMID: 12732320

Seki, M., M. Narusaka, H. Abe, M. Kasuga and K. Yamaguchi-Shinozaki et al., 2001. Monitoring the expression pattern of 1300 Arabidopsis genes under drought and cold stresses by using a fulllength cDNA microarray. Plant Cell, 13: 61-72. PMID: 11158529

Shinozaki, K. and K. Yamaguchi-Shinozaki, 2000. Molecular responses to dehydration and low temperature: differences and cross-talk between two stress signaling pathways. Curr. Opin. Plant Biol., 3: 217-223. PMID: 10837265

Spychalla, J.P. and S.L. Desborough, 1990. Superoxide dismutase, catalaseand $\alpha$-tocopherol content of stored potato tubers. Plant Physiol., 94: 1214-1218. PMCID: PMC1077364

Sreenivasan, T.V., B.S. Ahooliwalia and D.J. Heinz, 1987. Cytogenetics. In: Sugarcane Improvement Through Breeding. Heinz, D.J. (Ed.). Elsevier, Amsterdam, ISBN: 0444427694, pp: 211-253.

Takahashi, M.A. and K. Asada, 1983. Superoxide anion permeability of phospholipid membranes and chloroplast thylakoids. Arch. Biochem. Biophys., 226: 558-566. PMID: 6314906 
Ussuf, K.K., N.H. Laxmi and R. Mitra, 2001. Proteinase inhibitors: Plant-derived genes of insecticidal protein for developing insect-resistant transgenic plants. Curr. Sci., 80: 847-853. http://www.ias.ac.in/currsci/apr102001/847.pdf

Wang, Y., J. Jiang, X. Zhao, G. Liu, C. Yang and L. Zhan, 2006. A novel LEA gene from Tamarix and rossowii confers drought tolerance in transgenic tobacco. Plant Sci., 171: 655-662. DOI: 10.1016/j.plantsci.2006.06.011

Wechsberg, G.E., C.M. Bray and R.J. Probert, 1994. Expression of dehydrin-like proteins in orthodox seeds of Ranunculus sceleratus during development and water stress. Seed Sci. Res., 4: 241-246. DOI: 10.1017/S0960258500002221

Workman, D., 2007. Top ten sugar exporters. http://world-trade-organization.suite101.com

Wu, G., A.J. Robertson, P. Zheng, X. Liu and L.V. Gusta, 2005. Identification and immunogold localization of a novel bromegrass (Bromus inermis Leyss) peroxisome channel protein induced by ABA, cold and drought stresses and late embryogenesis. Gene, 363: 77-84. PMID: 16226403
Yamaguchi-Shinozaki, K., M. Kasuga, Q. Liu, K. Nakashima and Y. Sakuma et al., 2002. Biological mechanisms of drought stress response. JIRCAS Working Report, pp: 1-8. http://sciencelinks.jp/jeast/article/200212/000020021202A0337721.php

Zang, X. and S. Komatsu, 2007. A proteomics approach for identifying osmotic-stress-related proteins in rice. Phytochemistry, 68: 426-437. PMID: 17169384

Zhang, S.Z., B.P. Yang, C.L. Feng, R.K. Chen and J.P. Luo et al., 2006. Expression of the Grifola frondosa trehalose synthase gene and improvement of drought-tolerance in sugarcane (Sacchrum officinarum L.). J. Integr. Plant Biol., 48: 453-459. DOI: $10.1111 / \mathrm{j} .1744-7909.2006 .00246 . x$ 